\title{
SHAREHOLDER LEDGER USING DISTRIBUTED LEDGER TECHNOLOGY: THE ESTONIAN PERSPECTIVE
}

\author{
by
}

ANNE VEERPALU*

The article focuses on whether it is possible to use new technologies such as distributed ledger technology (DLT) in shareholder ledger maintenance systems. The article uses Estonia as an example to describe the shortcomings of shareholder ledger maintenance regulation and possible suggestions for reform and applies the principle of technology-neutrality to the subject matter to assess whether the regulation allows the adoption of new technologies, such as DLT, in ledger maintenance. The aim of the principle of technology-neutrality is to secure that the regulator does not create regulation that prefers any particular technology and discriminates against other technologies. Any regulation that is built around a pre-existing technology could suffer from preferring the use of that particular technology and consequently hinder innovation. In the article it is examined whether the ledger maintenance models used in Estonia are benefitting or suffering from the non-existence of technology-neutral technical standards for ledger maintenance and whether the differentiation of treatment of shareholder ledger administrators is justified on the basis of the principle of technology-neutrality.

\section{KEY WORDS}

Distributed Ledger Technology, DLT-Specific Legislation, Shareholder Ledger Administration, Technology-Neutrality Principle

anne.veerpalu@njordlaw.ee, Ph.D. Candidate in Information Technology Law, Law School, Tartu University, Estonia. 


\section{INTRODUCTION}

Shareholder ledgers are used to indicate the names of the shareholders of a business entity divided by shares. Typically, nowadays shares are held in book entry form and no certificates are issued to shareholders. This means that the ownership of a share is proven primarily on the basis of the ledger data - usually in computerized- or paper-format. Consequently, a ledger is also the source of data on the eligibility to earn dividends and on who controls the company. There can be only one trustworthy source of truth regarding shareholders and the shareholding structure. The ledger data must be complete and accurate at all times. Therefore, the ledger's reliability is of crucial importance and in order to ensure the reliability of ledger data - appropriate rules and safeguards must be placed on the procedures to amend the ledger data. Hence, the regulation on shareholder ledger administration is concerned with certainty about the ledger data and the transparency regarding how the ledger data can be amended. However, the rules and procedures regulating ledgers should make it easy to access it, yet, at the same time easy for shareholders to transfer the share.

The article will use Estonia as a use case to test whether the existing regulation allows the use of new innovative technology such as DLT in shareholder ledger maintenance. Why specifically DLT? Primarily, because DLT is a ledger technology and shareholder ledger is primarily a ledger - hence, the question: Would this be a beneficial match for the obligated parties tasked with ledger maintenance and for the shareholders desiring liquidity and transparency? Secondly, because France and the State of Delaware in the US have introduced DLT-specific legislation in similar context hoping to innovate their shareholder ledger maintenance system. Estonia was chosen as a use case because Estonia continues to market itself as the "blockchain nation"1 due to the almost decade long use of timestamping technologies (now also referred to as private blockchain) on its public registries. Given this background Estonia should be an ideal testbed for DLT applications in shareholder ledger maintenance.

The article focuses on shareholder ledgers of private limited liability companies in Estonia - osaühing (OÜ) because the majority of the Estonian

Korjus, K. (2017) Welcome to the blockchain nation. [blog entry] Medium Blog, 7 July 2017. Available from: https://medium.com/e-residency-blog/welcome-to-the-blockchain-nation5d9b46c06fd4 [Accessed 20 January 2019]. 
legal entities are OÜs. According to $\S 148(6)$ of the Estonian Commercial $\operatorname{Code}^{2}(\mathrm{CC})$, no certificates are issued for the shares of OÜs and shares are held in book entry form. CC requires that a shareholder ledger must be administered (meaning it is not optional) and there can be only one ledger per business entity.

At the moment there are two ways to administer an OÜ's shareholder ledger in Estonia: (i) management board as the administrator or (ii) Central Securities Depository (CSD) as the administrator. As of March 2018, only $1.7 \%$ of all OÜs $\left(178,513\right.$ in total) had registered their shares at the CSD. ${ }^{3}$ This means that although this alternative has been around for almost two decades, most companies have chosen not to register their shares at the CSD. The popularity of the use of the service of CSDs has not increased also after the transposition of $\mathrm{CSDR}^{4}$ in Estonia which opened the national market for cross-border services of other CSDs. While the unpopularity of the CSDs is most likely linked to applicable fees and the difficulty in fulfilling the precondition for registration - the need to have a bank and securities account in an Estonian commercial bank for each shareholder - due to anti-money laundering (AML) requirements applicable to banks. This precondition virtually excludes companies with non-resident shareholders from using CSD alternative.

Consequently, vast majority of shareholder ledgers in Estonia are administered by management boards. This coincides with the dominant practice in other European countries, e.g. the UK, Sweden, Finland, Latvia, Germany, the Netherlands and Denmark where companies administer their shareholder ledgers themselves. ${ }^{5}$ This said, however, the reality at the moment is that management boards in Estonia are administering the ledgers rather poorly or not at all.

2 Commercial Code (Äriseadustik) 1995. Estonia: Riigi Teataja (State Gazette). RT I 1995, 26, 355 in Estonian.

3 Chamber of Notaries. (2018) Notarite Koja arvamus ühinguõiguse revisjoni muudatusettepanekute kohta, Opinion on the analysis-concept paper of company law revision working group, 17th December 2018, p. 2. [online] Available from: https://www.just.ee/sites/ www.just.ee/files/notarite_koja_arvamus_18.12.2018.pdf [Accessed 12 January 2019].

4 Regulation (EU) No 909/2014 of the European Parliament and of the Council of 23 July 2014 on improving securities settlement in the European Union and on central securities depositories and amending Directives 98/26/EC and 2014/65/EU and Regulation (EU) No 236/2012. Text with EEA relevance. OJ L 257, 28. 8. 2014, pp. 1-72 (CSDR).

5 Ministry of Justice. (2018) Ühinguõiguse revisjon Analüüs-kontseptsioon (Revision of Company Law, hereinafter Analysis-concept paper), 15 September 2018, p. 489. [online] Available from: https://www.just.ee/sites/www.just.ee/files/uhinguoiguse_revisjoni_analuus-

kontseptsioon.pdf [Accessed 12 January 2019]. 
While globally registries and ledgers have seen a shift from offline to online, no such development regarding shareholder ledgers has taken place in Estonia as majority of the ledgers maintained by the management boards are kept in oral- or paper-format. Furthermore, this means that under the CC the majority of share transfer transactions in Estonia need to be authenticated by the notary. As can be seen in section 3 of the article, the notaries authenticating these share transfer transactions do not trust the shareholder ledgers maintained by management board but rather trust the "unofficial" duplication of ledger data by Commercial Register (CR). ${ }^{6}$ Neither the national nor regional $\operatorname{law}^{7}$ requires such duplication or disclosure of shareholder data in the CR. Consequently, such practice of "unofficial" duplication of records at CR devalues the CR data as majority of CR data is reliable and official. However, the shareholder data the CR contains is not constitutive, not binding and unreliable under the law. This concerning practise among other issues has led the Ministry of Justice as part of their company law codification plan to take the initiative to reform also the current shareholder ledger maintenance regulation.

Consequently, the research question posed in the article is whether the existing regulation and reform ideas of ledger maintenance in Estonia are open to the use of new innovative technologies, such as DLT, or are there amendments needed for any technological innovation to be used in this area of application?

In order to address the research question, first, in section 2, an introduction will be provided to DLT including an overview of the developments in the area of DLT-specific regulatory initiatives addressing share registries and shareholder ledgers in France and the State of Delaware in the US. Thereafter, in section 3 the development of the regulation of the two separate ledger maintenance models in Estonia are discussed along with the concerns these face. Each concern is followed

\footnotetext{
Commercial Register is the registration department of Tartu County Court that maintains the register of the enterprises of sole proprietors and companies located in Estonia. Section 22(1) of CC.

7 Directive 2009/101/EC of the European Parliament and of the Council of 16 September 2009 on coordination of safeguards which, for the protection of the interests of members and third parties, are required by Member States of companies within the meaning of the second paragraph of Article 48 of the Treaty, with a view to making such safeguards equivalent (Text with EEA relevance). OJ L 258, 1. 10. 2009, pp. 11-19. Directive (EU) 2017/1132 of the European Parliament and of the Council of 14 June 2017 relating to certain aspects of company law (Text with EEA relevance). OJ L 169, 30. 6. 2017, pp. 46-127.
} 
by a theoretical applications of DLT-based ledger system to solve these concerns.

Finally, in section 4 the author addresses the possibility to use DLT in ledger maintenance addressing the regulation's susceptibility to the use of new technologies. The approach is primarily based the application of the principle of technology-neutrality, which is a principle supporting both innovation and competition, and the author assesses the compliance of the current regulation and reform ideas with the said principle. As the author has discussed the principle at length in one of her previous articles, $^{8}$ the principle will be introduced only briefly in section 4 of the article.

Although the issues are approached as a case study from the point of view of Estonian law, similar questions can be raised in other legal systems, hence, the topic is both relevant and has global application.

\section{DLT AND DLT-SPECIFIC LEGISLATION}

In this section technology at hand and legislative initiatives targeting shareholder ledgers or share registries with the said technology from the State of Delaware, US and France are briefly discussed in order to contextualize the discussion that follows.

\subsection{INTRODUCTION TO DLT}

As regards technology, this article is concerned with the use of blockchain and distributed ledger technology (DLT). It can be argued that every blockchain is a distributed ledger, but not every distributed ledger is a blockchain. ${ }^{9}$ For the purposes of this article, no distinction is made between blockchain and DLT.

Why is the technology at all called blockchain? Blockchain technology bears such a name for the reason that it groups data into blocks and the blocks into a secured chain using cryptography. ${ }^{10}$ The chain grows

8 Veerpalu, A. (2018) Decentralised Technology and Technology Neutrality in Legal Rules: An Analysis of De Voogd and Hedqvist. Baltic Journal of Law E Politics, 11 (2), pp. 61-94. doi: https://doi.org/10.2478/bjlp-2018-0011

9 Shaan, R. (2018) The Difference Between Blockchains \& Distributed Ledger Technology. [blog entry] Medium Blog Towards Data Science. Available from: https://towardsdatascience.com /the-difference-between-blockchains-distributed-ledger-technology-42715a0fa92 [Accessed 01 May 2018].

10 Cuccuru, P. (2017) Beyond bitcoin: An early overview on smart contracts. International Journal of Law and Information Technology, 25 (3), pp. 179-195. [online] Available from: https://doi.org/10.1093/ijlit/eax003 [Accessed 30 May 2018]. 
indefinitely forming a list of records of transactions which only allows to append to it and does not allow to delete a block in between blocks. The block contains information about previous blocks of transactions and the current ledger entries and timestamps the status of the ledger making the ledger theoretically immutable. Immutability makes blockchain technology well-suited for administering registries, processing transactions and tracing ownership.

And what exactly is a distributed ledger? In the case of traditional databases a single entity or a person keeps the original copy of the database, while there may be other copies, these are merely backups of the original and not authoritative source of data. For this reason, these databases are also referred to as centrally governed or centralised databases. However, any database that is not centrally governed or centralised but instead the administration of which is distributed among various parties (i.e. nodes) can be called a distributed database or simply a distributed ledger.

Yet, DLT is not only about the database. DLT binds together many technologies that already existed earlier - such as peer-to-peer networks ${ }^{11}$, consensus mechanism ${ }^{12}$, cryptography ${ }^{13}$ and linked timestamping ${ }^{14}$. The aim of the mix of these technologies is to achieve a transparent, highly resilient, tamper-resistant database operated by a decentralized or distributed network. $^{15}$

There are two primary types of distributed ledgers depending on the openness to participation and consensus typology: permissionless (public) and permissioned (private). Permissioned means that participants in the consensus mechanism are pre-selected and access to the network is

11 Nakamoto, S. (2008) Bitcoin: Peer-to-peer Electronic Cash System. [online] Available from: https://bitcoin.org/bitcoin.pdf [Accessed 12. April 2018].

12 According to De Filippi, P. and Wright, A.: "a consensus mechanism - a set of strict rules with predefined incentives and cost structures - which makes it difficult and costly for any one party to unilaterally remove or modify data stored on a blockchain. Consensus mechanisms help a blockchain-based network periodically reach agreement as to the current state of the shared database - even if members do not know or trust one another." De Filippi, P. and Wright, A. (2018) Blockchain and the Law: The rule of code. Harvard University Press, p. 2.

13 Ibid.

14 Among one of the fundamental concepts behind Bitcoin protocol is something called linked timestamping, the two cryptographers from an Estonian technology company GuardtimeAhto Buldas and Märt Saarepera - were the first to provide scientific evidence already in 2003 on what hash-functions and data structures are needed to give formal security proof. Guardtime (2019). [online] Available from: https://guardtime.com/technology [Accessed 14 January 2019].

15 De Filippi, P. and Wright A. (2018) Op. cit., p. 2. 
restricted (e.g. R3 Corda $a^{16}$ and Hyperledger Fabric ${ }^{17}$ ). Permissionless ledgers, on the other hand, allow anyone to participate in the network and also in the consensus mechanism (e.g. Bitcoin and Ethereum ${ }^{18}$ ). Both Bitcoin's and Ethereum's protocol is open-sourced. The most well-known DLT network is based on permissionless Bitcoin protocol, which

"supports decentralized, global value transfer systems that are both transnational and pseudonymous." 19

Ethereum is a permissionless ledger that

"has a Nakamoto-style consensus protocol that relies on a distributed set of miners ${ }^{\prime 20}$

to continue existing and takes the protocol further than Bitcoin allowing scripts that are generally referred to as "smart contracts". ${ }^{21}$

Broadly speaking, the protocol of blockchain and DLT can be used to maintain a ledger of data, assets or rights. The unit of the ledger is the "vehicle of data" for anything - reprsenting tangible assets (house, car, key) or intangible assets (license, access keys, in-game items, securities).

After this short introduction to DLT, the next subsection will introduce the regulative initiatives in using DLT in shareholder ledger maintenance systems.

\subsection{DLT-SPECIFIC RELEVANT LEGISLATION}

Some jurisdictions are more prepared for the use of DLT than others and have as a result created DLT-specific legislation. For the purposes of the current article only the ones applicable to shareholder ledgers and share registries will be introduced. By no account does this section aim

16 Corda, a protocol of a distributed database technology company R3CEV LLC that leads a consortium of more than 200 firms in research and development of distributed ledger usage in the financial system. Wikipedia. (2018) Corda. [online] Available from: https://en. wikipedia.org/wiki/R3_(company)\#Corda [Accessed 14 January 2018].

17 Hyperledger Fabric is a Linux Foundation built blockchain framework and operates as plug-and-play model.

18 Wikipedia. (2019) Ethereum. [online] Available from: https://en.wikipedia.org/wiki/ Ethereum [Accessed 14 January 2019].

19 De Filippi, P. and Wright A. (2018) Op. cit., p. 3. Pseudonyms are identifiers of a person or persons that operate like placeholders as they mark an identity, yet the identity is unknown.

20 McCorry, P., Hicks, A. and Meikeljohn, S. (2018) Smart contracts for bribing miners. Conference Proceedings The 5th Workshop on Bitcoin and Blockchain Research 2nd March 2018, p. 4. Available from: https://fc18.ifca.ai/bitcoin/schedule.html [Accessed 03 May 2018].

${ }^{21}$ Ibid. 
to provide a comprehensive overview of these sort of initiatives as there might be others with the same aim the author is not aware of.

\subsubsection{STATE OF DELAWARE, US}

On 2nd of May 2016 Delaware's Governor announced the launch of Delaware Blockchain Initiative. For Delaware, the change embracing DLT was revolutionary as it allows a leap from record-keeping of ownership of public companies that was based on

"1970s-era technologies of depository institutions, jumbo paper certificates, and a centralized ledger". ${ }^{2}$

Most public company equities issued in the United States are held on the ledger not under their owner's names but under the name of an intermediary "record holder" and a broker keeps a second database of the actual shareholders behind the intermediary. ${ }^{23}$ The DLT-specific amendments allow

"companies and stockholders to enjoy the benefits of electronic trading while maintaining direct ownership of their shares". ${ }^{24}$

So the aim of the amendments was to increase transparency, liquidity and access to shares as DLT use allows for easy access, easy transfer and transparency regarding shareholders. The amendments allowing DLT's use entered into effect on 1st August 2017 with the Senate Bill 69. ${ }^{25}$ As explained in the Synopsis ${ }^{26}$ of the Senate Bill 69 to amend the General Corporation Law of the State of Delaware (DGCL):

22 Stromberg G. T. et al. (2018) Are Headwinds Hampering Delaware's Blockchain Initiative? [blog entry] Law 360 blog, 23 March 2018. Available from: https://jenner.com/system/assets/ publications/17844/original/stromberg\%20Law360\%20March\%2023\%202018.pdf?1521837416 [Accessed 14 January 2019].

23 Ibid.

24 Lucking, D. (2017) Delaware Passes Law Permitting Companies to Use Blockchain Technology to Issue and Track Shares. Allen \& Overy publications, 26 September 2017. [online] Available from: http://www.allenovery.com/publications/en-gb/Pages/Delaware-Passes-LawPermitting-Companies-to-Use-Blockchain-Technology-to-Issue-and-Track-Shares-.aspx [Accessed 05 May 2019].

25 Polner, G. et al. (2017) Delaware Approves Use of Blockchain in New DGCL Amendments. Gibson Dunn Securities Regulation and Corporate Governance Monitor, 31 July 2017. [online] Available from: http://securitiesregulationmonitor.com/Lists/Posts/Post.aspx?ID=299 [Accessed 07 May 2018].

${ }^{26}$ Delaware State Senate 149th General Assembly Senate Bill No. 69 An act to amend title 8 of the Delaware Code Relating to the General Corporation Law. [online] Available from: https://legis.delaware.gov/json/BillDetail/GenerateHtmlDocument?legislationId=25730\& legislationTypeId=1\&docTypeId=2\&legislationName=SB69 [Accessed 07 May 2018]. 
"amendments to Sections 219, 224 and 232 and related provisions are intended to provide specific statutory authority for Delaware corporations to use networks of electronic databases (examples of which are described currently as "distributed ledgers" or a "blockchain") for the creation and maintenance of corporate records, including the corporation's stock ledger."

There are certain legislative requirements for the ledger, such as that it must:

"(i) allow the production of a record of the company's stockholders;

(ii) record certain mandatory information; and (iii) permit transfer of stock" ${ }^{27}$

Plus the ledger must also "be capable of being converted into 'clearly legible paper form" ${ }^{\prime \prime 28}$, which must be "valid and admissible in evidence". 29 Furthermore, the Delaware Division of Corporations also operates a node on the permissioned DLT network for authenticating the stock issuance. ${ }^{30}$

For the purpose of providing a solution in line with the registration, the state of Delaware partnered with a DLT start-up called Symbiont ${ }^{31}$ who built an application called Smart Securities. ${ }^{32}$ Symbiont itself runs a permissioned private ledger on its own non-open-sourced protocol.

Since then several other states in the United States (e.g. Arizona, Nevada, Wyoming) have followed this example and amended their laws to cater to the use of DLT technology in corporate governance. ${ }^{33}$ Among these, the most noteworthy is a bill entitled "Corporate stock-certificate tokens" that was proposed on 16th January 2019 in Wyoming - after earlier

27 Lucking, D. (2017) Op. cit.

28 Ibid.

29 Ibid.

30 Ibid.

31 According to a blog by the chairman and president of Symbiont Caitlin Long its legal team also assisted also in drafting the DGCL's DLT-specific amendments. Long, C. (2018) Blockchain crosses the Delaware. [blog entry] Mediamarkets blog, 31 July 2018. Available from: https://www.marketsmedia.com/blockchain-crosses-delaware/ [Accessed 07 May 2018].

32 Allison, I. (2015) Smart securities issuer Symbiont fires shots in the private blockchain arms race. [online] International Business Times, 28 September 2015. Available from: https://www.ibtimes.co.uk/smart-securities-issuer-symbiont-fires-shots-private-blockchainarms-race-1521449 [Accessed 08 May 2018].

33 Song, W. (2018) Bullish on blockchain: examining Delaware's approach to distributed ledger technology in corporate governance law and beyond. Harvard Law Review. Available from: http://www.hblr.org/2018/01/bullish-on-blockchain-examining-delawares-approachto-distributed-ledger-technology-in-corporate-governance-law-and-beyond/ [Accessed 07 May 2018]. 
DLT-specific legislative initiatives ${ }^{34}$ - with the aim to tokenize shares and place certificates of share ownership on blockchain. ${ }^{35}$ This proposal would be replacing the paper-format certificates used in Wyoming for digital share certificates. ${ }^{36}$

\subsubsection{FRANCE}

DLT-specific legislative initiatives also sprung up in Europe: in Malta, Switzerland, Gibraltar, yet, the most relevant for the current article are the legislative initiatives of France. Similarly to Estonia, securities are issued in book-entry form in France. ${ }^{37}$ The title to securities is reflected by way of amending the records of

"a securities account held by the issuer, a central securities depository (CSD) or a securities custodian". ${ }^{38}$

France first implemented regulation in relation to blockchain technology ${ }^{39}$ in relation to trading of minibonds in 2016. In 2017 it expanded the regulation also to securities. ${ }^{40}$ On 9th December 2017, the French government presented order No 2017-1674 (DLT Order) regarding the use of DLT for the recording and transmission of securities. ${ }^{41}$ The DLT Order

34 ConsenSys. (2018) Wyoming Passes 5 Pro-Blockchain Laws, Points the Way in Digital Asset Regulation. [blog entry] Medium blog, 15 March 2018. Available from: https://media. consensys.net/wyoming-passes-5-pro-blockchain-laws-points-the-way-in-digital-assetregulation-6fae9e07d129 [Accessed 27 January 2019].

35 Nicholson, G. (2019) Wyoming Proposes Bill for Issuance of Tokenised Certificates with Stocks. [blog entry] TokenMarket, 17 January 2019. Available from: https://tokenmarket.net/news/ regulation/wyoming-proposes-bill-issuance-tokenised-certificates-stocks/ [Accessed 23 January 2019].

36 Proposal HB0185 named Corporate stock-certificate tokens. [online] Available from: https://www.wyoleg.gov/Legislation/2019/HB0185 [Accessed 23 January 2019].

37 Report to the President of the Republic relating to Ordinance No. 2017-1674 of 8 December 2017 on the use of a shared electronic registration device for the representation and transmission of financial securities, Rapport au Président de la République relatif à l'ordonnance $n^{\circ}$ 2017-1674 du 8 décembre 2017 relative à l'utilisation d'un dispositif d'enregistrement électronique partagé pour la représentation et la transmission de titres financiers. Published in JORF $n^{\circ} 0287$ du 9 décembre 2017 texte $n^{\circ} 23$. [online] Available from: https://www.legifrance.gouv. fr/eli/rapport/2017/12/9/ECOT1729053P/jo/texte [Accessed 01 May 2018].

38 Clifford Chance. (2018) France pioneers blockchain legal framework for unlisted securities. Law Firm Briefing Note, January 2018. Available from: https://www.cliffordchance.com/ content/dam/cliffordchance/PDFDocuments/Client $\% 20$ Briefing\%20-\%20France $\% 20-\% 20$ Blockchain\%20for\%20unlisted\%20securities\%20180750-4-2....pdf [Accessed 22 April 2018].

39 Vocabulaire de l'informatique (liste de termes, expressions et définitions adoptés) published in JORF $n^{\circ} 0121$ du 23 mai 2017 texte $n^{\circ} 20$. Available from: https://www.legifrance.gouv.fr/ affichTexte.do?cidTexte=JORFTEXT000034795042\&categorieLien=id [Accessed 1 May 2018].

40 DLT was defined as "a method of recording continuously generated data as blocks linked to each other in the chronological order of their validation, each block and its sequence being protected against modification".

${ }^{41}$ Clifford Chance. (2018) Op. cit., p. 1. 
covers only the categories of securities not admitted to the CSD under CSDR. Hence, the DLT Order regulates unlisted equity securities issued by joint stock companies, ${ }^{42}$ units or shares of collective investment undertakings, negotiable debt securities such as bonds. ${ }^{43}$

The main advantage of the DLT Order is that it allows for multiplicity of shareholder ledger administrators to advance competition and better user experience in addition to CSD. Furthermore, the registration of securities on DLT is under the law comparable in effect to the registration of securities at CSD, so that all benefits CSD-registered instruments enjoy are extended to DLT-registered instruments also. The intention of the French initiative was to increase liquidity so that the transfer of securities isallowed from account-to-account or wallet-to-wallet seamlessly. ${ }^{44}$

\section{REGULATION AND REFORM IDEAS OF LEDGER ADMINISTRATION IN ESTONIA}

In this section the existing regulation on and reform ideas of shareholder ledger maintenance in Estonia are introduced. The section also portrays observations made about ledger maintenance practise and draws out the concerns with the system in order to conduct the analysis of the research question in section 4 .

\subsection{CURRENT LEGISLATION ON SHAREHOLDER LEDGERS IN ESTONIA}

Under the CC, there are two ways to administer shareholder ledger of an OÜ: (i) by the management board or (ii) by CSD, which maintains the Estonian register of securities under an administrative agreement with the state. The latter option is voluntary and quite unpopular as it is used only by $1.7 \%$ of OÜs in Estonia. This means that most of the shareholder ledgers are administered by management boards. This coincides with the dominant practice in other European countries such as, for instance, the UK, Sweden, Finland, Latvia, Germany, the Netherlands and Denmark. ${ }^{45}$

\footnotetext{
$42 \quad$ Ibid, p. 2.

43 Ibid, p. 1.

44 Ibid, pp. 1-2.
} 


\subsection{ROLE OF COMMERCIAL REGISTER}

The Commercial Register (CR) is for information purposes replicating majority of the ledger data directly from the source or the notaries. The national and regiona $\mathrm{l}^{46}$ law does not obligate $\mathrm{CR}$ to record this data. The data entered into the $\mathrm{CR}$ about the shareholders ${ }^{47}$ has (i) no legal meaning, (ii) no constitutive value and (iii) cannot be relied on by third parties as binding. ${ }^{48}$

\subsection{CSD-ADMINISTERED SHAREHOLDER LEDGER}

The possibility to register OÜ's shares in the CSD and to allow the shareholder ledger to be administered by CSD was introduced already in 2001. ${ }^{49}$ In 2017 CSDR transposition opened the market to multiple CSDs. ${ }^{50}$ The goal of the CSD was to ensure that there would be unity and truthfulness of data. CSD data serves as a source of positive and negative trust. Positive trust means that a person in good faith can trust the data on the securities account is correct, while negative trust means that a person in good faith can trust that the rights that are not represented on the securities account do not exist. ${ }^{51}$ In case shares of an OÜ are registered at CSD no shareholder ledger is maintained by the management board. ${ }^{52}$ The registration, which is subject to multiple fees, is voluntary and very rarely used.

The ledger maintained by the CSD is a public ledger and falls under the definition of a "database" under the Public Information Act $^{53}$ (IPA).

45 Ministry of Justice. (2018) Ühinguõiguse revisjon Analüüs-konseptsioon (Revision of Company Law), 15 September 2018. [online] Available from: https://www.just.ee/sites/www.just.ee/ files/uhinguoiguse_revisjoni_analuus-kontseptsioon.pdf [Accessed 12 January 2019], p. 489.

46 According to Articles 14 and 16 of the Directive 2017/1132 there is no disclosure obligation regarding shareholders in commercial registries of the Member States. Directive (EU) 2017/1132 of the European Parliament and of the Council of 14 June 2017 relating to certain aspects of company law (Text with EEA relevance). Official Journal of the European Union 169, 30 June 2017, pp. 46-127. Available from: https://eur-lex.europa.eu/legal-content/EN/TXT/? uri=CELEX\%3A32017L1132 [Accessed 20 May 2019].

47 Section 144(1) point 31) of CC.

48 Case no 3-2-1-163-11 (2012), Estonian Supreme Court (Civil Chamber), 22 February 2012, para. 33; Case no 3-2-1-133-11 (2011), Estonian Supreme Court (Civil Chamber), 14 December 2011, para. 24; Saare, K. et al, Ühinguõigus I, Juura, 2015, pp. 53-54.

49 Estonian Central Register of Securities Act (Eesti väärtpaberite keskregistri seadus) 2001. Estonia: Riigi Teataja (State Gazette). RT 2000, 57, 373, in Estonian.

50 Securities Register Maintenance Act (SRMA) (Väärtpaberite registri pidamise seadus) 2017. Estonia: Riigi Teataja (State Gazette). RT I, 26.06.2017, 1 in Estonian.

51 Case no. 3-4-1-3-12 (2012) Estonian Supreme Court (Constitutional Review Chamber), 6 July 2012, para. 52.

$52 \S 2(3)$ of SRMA. 
The data therein must be more accessible than data maintained by management boards. According to IPA $\S 43^{3}$

"before the establishment of a database [...] the technical documentation of the database shall be approved by the Estonian Information System's Authority, the Data Protection Inspectorate and the Statistics Estonia".

This means the IPA requires CSD maintained ledger to go through vigorous checks and certification by various authorities. Any CSD wishing to use a DLT-based ledger application would have to go through the same checks and verifications.

Under the SRMA $\S 1^{2}(2)$ the CSD is a database belonging to the state information system. In essence the CSD ledger must comply with the three-level IT baseline security system. ${ }^{54}$ The CSD ledger needs to be centrally controlled as the obligated subject must enter into an agreement with the state to maintain the ledger. Similarly, any DLT-based ledger application the CSD wishes to use needs to be operated also centrally and meet the IT baseline security system requirements.

Further from the technical requirements, the registration of shares in CSD requires the existence of a securities account with the CSD for every shareholder, which presumes the opening of a bank and securities account by an account operator ${ }^{55}$ such as a bank. As of 1 January 2019 as a solution to the overall difficulty of opening the necessary accounts due to AML concerns there is also an option for the OÜ to open a deposit account with the CSD for an additional fee in the name of the shareholder. In addition, professional participants have the right to open a nominee account for holding the shares for and on behalf of another person. ${ }^{56}$ Therefore, the CSD's role is to merely aggregate the data recorded on the securities, deposit and nominee accounts to represent this on the centralised shareholder ledger and also send the data to CR.

53 Public Information Act (Avaliku teabe seadus) 2001. Estonia: Riigi Teataja (State Gazette). RT I 2000, 92, 597, in Estonian.

54 State Information System Website. Available from: https://www.ria.ee/en/cyber-security/itbaseline-security-system-iske.html [Accessed 02 June 2019].

55 Account operator is a professional participant in the Estonian securities market, Eesti Pank (Central Bank of Estonia), an investment firm, credit institution, operator of the regulated market or operator of a securities settlement system registered in a Member State or in a third country in case of further pre-conditions. SRMA § 11(1), SRMA § 11(1).

56 SRMA § 6(1) and (2). 
Similar aggregation of data into $\mathrm{CR}$ could be also done with ledgers operating on DLT. Yet, the DLT-based ledgers would most likely be able to offer more flexibility in opening wallets or accounts to users as these DLT-applications would not have as strict AML requirements as banks on which the CSD system depends upon.

\subsection{LEDGERS MAINTAINED BY MANAGEMENT BOARDS}

The shareholder ledger maintained by the management board is not a public ledger. The regulation on the management board-administered ledger does not prescribe that it must be in any particular media or form and therefore, it can be in any media or form and using any technology applications chosen by the management board.

According to notaries and legal practitioners, standard practice demonstrates that management boards do not actually administer shareholder ledgers at all or do it in oral form. ${ }^{57}$ As non-CSD-registered share transfer transactions need to be authenticated by the notary, the practise shows that prior to authentication of the transaction the notaries merely copy shareholder data off the $\mathrm{CR}$ and ask the management board to confirm it with signature. This is a somewhat risky practice as the $\mathrm{CR}$ also updates its data based on annual reports and that could make CR data incorrect. $^{58}$

To mitigate this risk there is common, yet, unnecessary ${ }^{59}$ practice among notaries to verify the $C R$ data by requiring the seller to submit a copy of the share acquisition transaction document. ${ }^{60}$ The only plausible risk the notary actually needs to mitigate is that there has not been another transaction that has not yet been reported to the $\mathrm{CR}$ as according to the law the notaries have to report transactions within two working days. However,

57 Alekand A. (2015) Osaühingu osanikeregistri pidamine. Juridica I 2015, p. 10. Available from: https://www.juridica.ee/article_full.php?uri=2015_1_osa_hingu_osanikeregistri_ pidamine\&pdf $=1$ [Accessed 04 January 2019].

58 The data will be entered on the basis of share transfer notice, share capital increase or decrease resolution by shareholders or on the basis of the shareholder ledger appended to annual report. Ibid, p. 13. See also Decree of the Minister of Justice no 60 (2012), Statute of the registry department of the court (Kohtu registriosakonna kodukord), 19 December 2012, RT I, 28. 12. 2012, 10.

${ }^{59}$ It is unnecessary as notaries themselves can check the source of the entry into CR and do not have to double-check the previous transaction documents.

${ }^{60}$ The system is even more bureaucratic due to the practice that if the same notary who is about to authenticate the planned transaction has authenticated also the previous transaction reported to the Commercial Register then the notary will demand the seller to still submit the copy of the previous transaction document and not check it themselves from their notarial register of documents. 
this risk is not mitigated by requesting the acquisition document from the seller, but would rather be mitigated in case transactions would be recorded in the ledger instantaneously with a technological application such as for example DLT.

\subsection{DIFFERENCES IN SHARE TRANSFERS}

There are differences in share transfer rules depending on whether the shares are registered or not registered at CSD.

\subsubsection{LEDGER ADMINISTERED BY MANAGEMENT BOARD}

For the transfer of non-CSD registered shares there is a limitation of the principle of freedom of form ${ }^{61}$ as notary authenticated transactions are required for both the obligations constituting contract and the real right contract. $^{62}$ The required notarial authentication can only be done by an Estonian notary practicing in Estonia and not by a notary in any other jurisdiction of the world. ${ }^{63}$ The primary aim of establishing the authentication requirement for share transfer transactions of OÜs was to guarantee legal certainty. ${ }^{64}$ Should the parties to a transaction fail to comply with the statutory notarial authentication form requirement, the transaction is void. ${ }^{65}$

The notarial authentication requirement was not in the CC from the adoption of the CC as it was introduced in $1998 .{ }^{66}$ Its initial absence was named as the "single biggest minus of the Commercial Code"67 as entries of the shareholder ledger lacked credibility. According to the case-law of the Estonian Supreme Court, the aim of the notarial authentication requirement is not merely documenting a transaction (evidentiary function ${ }^{68}$ )

\footnotetext{
61 Sein, K. Tehingu vorminõuded ja nende järgimata jätmise tagajärjed, Juridica VII 2010, p. 509; Section 77 (1) of the GPCCA. General Part of the Civil Code Act (Tsiviilseadustiku üldosa seadus) 2002. Estonia: Riigi Teataja (State Gazette), RT 2002, 35, 216, in Estonian (GPCCA); $\S 8(1)$ and $\S 11(1)$ of the Law of Obligations Act (Võlaõigusseadus) 2001. Estonia: Riigi Teataja (State Gazette) RT I 2001, 81, 487, in Estonian.

62 Section $149(4)$ of CC.

63 Section 82 of GPCCA, Section 56(4) of the Notarisation Act. Notarisation Act (Notariaadiseadus) 2001. Estonia: Riigi Teataja (State Gazette) RT I 2000, 104, 684, in Estonian.

64 Sein, K. (2010) Op. cit., p. 509.

65 § 83(1) of GPCCA.

66 Explanatory memorandum (744 SE) to the Act amending Commercial Code, Non-Profit Associations Act, Foundations Act and acts related to the above Äriseadustiku, mittetulundusühingute seaduse, sihtasutuste seaduse ning nendega seotud seaduste muntmise seaduse eelnõu 744 SE seletuskiri, 15 December 1997 (Explanatory memorandum (744 SE)).

67 Explanatory memorandum (744 SE), op. cit.

68 Sein, K. (2010) Op. cit., p. 509.
} 
and identifying the parties thereto (identification function), but also the protection of the parties (warning function ${ }^{69}$ ) themselves against rushed and hastily made transactions. The court has explained that the form requirement is there also to warn the parties and explain the legal consequences of the transactions to the parties (consulting function ${ }^{70}$ ).

Last but not least, notaries tasked to authenticate share transfer transactions can refuse to authenticate the transaction in case sufficient data of user's marital status, consent of spouse, property regime, acquisition document originals or any verified data on seller and buyer (in case of legal entities - registry card, certificate of good standing and incorporation) required by the notary are unavailable. This seriously hampers the liquidity of the shares and creates a subjective judgement linked obstacle to share transfer transactions that the type of transactions should already be able to overcome.

Any ledger operated on DLT certainly fulfils the evidentiary function as it reflects the execution of any transaction. The use of the DLT-based ledger could also enable the identification function on the basis of similar KYC requirements as applicable to custodial wallet and virtual currency exchange service providers under the 5th AML Directive. ${ }^{71}$ The warning functionality could be also built in the form of "click-the-box" if you understand the consequences of the transaction, but it is not comparable to warning function of the notary. However, the only function that would not be enabled at all with DLT-based system is the consulting function.

\subsubsection{LEDGERS ADMINISTERED BY CSD}

In the case of CSD-registered shares there is no form requirement for share tranfer transaction and freedom of form prevails.

${ }^{69}$ Case no 3-2-1-49-03, Case no 3-2-1-85-04 (2004), Estonian Supreme Court (Civil Chamber) 6 September 2004.

70 According to Section 18(1) of the Notarisation Act "the notary shall also explain to parties the meaning and legal consequences of the transaction and the different possibilities for entry into the transaction" and "the notary shall ensure that errors and doubts are precluded and the rights of inexperienced or incompetent parties are not damaged". See also Case no 3-2-1-49-03 (2003), Estonian Supreme Court (Civil Chamber) 13 May 2003; Case no 3-2-1-127-03 (2003), Estonian Supreme Court (Civil Chamber) 10 November 2003; Case no 3-2-1-141-14 (2015), Estonian Supreme Court (Civil Chamber), 28 January 2015, paras. 34-35.

71 Directive (EU) 2018/843 of the European Parliament and of the Council of 30 May 2018 amending Directive (EU) 2015/849 on the prevention of the use of the financial system for the purposes of money laundering or terrorist financing, and amending Directives 2009/138/EC and 2013/36/EU. Official Journal of the European Union 156, 19 June 2018, pp. 43-74 (5th AML Directive). Available from:https://eur-lex.europa.eu/legal-content/EN/ TXT/?uri=CELEX:32018L0843 [Accessed 30 May 2019]. 
The primary requirements for CSD-registered share transfers come from the SRMA and its implementation acts regarding securities transfers. The order to transfer the share is given either in writing ${ }^{72}$ or electronically ${ }^{73}$. When an order is given to a securities account administrator, it must perform the following tasks: (i) identification of client (identification function) and (ii) AML checks (e.g. inquiry into buyer's source of funds). The securities account operator does not check the existence of the transaction constituting the obligation or the real right contract and therefore, fulfils the evidentiary function only to a limited extent, as similarly to DLT-application based ledger, it merely sees the execution transaction intermediated by the account operator.

Similarly to any DLT-based ledger the account operator ${ }^{74}$ in case of CSD-registered shares is not obligated to perform any consulting or warning function. ${ }^{75}$ Hence, if the legislature did not see it necessary to require the fulfillment of these functions for CSD-registered share transactions, it should also be acceptable for the legislature that the DLT-based ledger solution fails to fulfil these functions.

\subsubsection{CONSTITUTIVE VALUE OF THE LEDGER ENTRY}

It is important to note that under the CC neither the entry in the shareholder ledger maintained by the management board nor the replication of data at $C R$ have constitutive value. Only the entry into CSD has constitutive value and is the basis for good faith acquisition of a share. ${ }^{76}$

Under the CC, the transfer of a share is deemed effected and a share is deemed to have transferred with respect to the OÜ in case the management board has been notified of the transfer of the share and received evidence thereof. ${ }^{77}$ Thus, even if the management board never amends the shareholder ledger according to the new status quo, from the company's perspective the share still has already transferred and the ledger reflects the shareholder status incorrectly.

\footnotetext{
72 GPCCA $\S 78(1)$.

GPCCA $\S 80(2)$.

74 Sein, K. (2010) Op.cit., p. 513.

75 Alekand, A. (2015) Op. cit., p. 14.

76 9(2) of SRMA.

$77 \S 150(1)$ of CC.
} 
Secondly, there is no constitutive value also in the entry of the shareholder data in the CR. This fact, however, decreases the value of the rest of the data recorded in the CR. If a third party cannot trust one data item in the CR why should it trust another. ${ }^{78}$ The status quo has created confusion also among courts themselves who have incorrectly relied on the CR shareholder data. ${ }^{79}$

Similarly to entries into CSD, the DLT-based ledger entries could enjoy constitutive value as again similarly to CSD the ledger entry is the result of a verified and immutable record of transaction that is secured by transparency of the ledger and its protocol.

\subsection{REFORM IDEAS}

In 2014, the Estonian Ministry of Justice initiated a company law codification project and by 2018 a working group was established by the Ministry that issued an analysis-concept paper ${ }^{80}$ providing an overview of identified shortcomings, relevant regulation in comparative jurisdictions and their suggestions for revision.

Coinciding with proposals made by the Estonian start-up community ${ }^{81}$ and the Estonian Bar Association ${ }^{82}$, the company law revision included a suggestion to ease the obligatory notarial authentication form requirement for non-CSD-registered share transfer transactions (both the obligationconstituting and the real right contract). ${ }^{83}$

The working group stated that most of the jurisdictions they looked at in their analysis for the purposes of comparison (i.e. Finland, Sweden, Latvia, Lithuania and Delaware) did not have an obligatory share transfer form requirement at all or there was merely written form for a real right

78 Kõve, V. (2013) Kas kinnistusraamatu ja teiste kohtulike registrite korraldus vajab reformi? (Does the Public Title Book and other court register organization demand a reform?). Juridica VII 2013, p. 461 Available from: https://www.juridica.ee/article_full.php?uri=2013_7_kas_ kinnistusraamatu_ja_teiste_kohtulike_registrite_korraldus_vajab_reformi_\&pdf $=1$ [Accessed 10 January 2018].

79 Ibid., p. 461. See also Case no 3-2-1-133-11, Estonian Supreme Court (Civil Chamber), 14 December 2011, para. 24; Case no 3-2-1-163-11, Estonian Supreme Court (Civil Chamber), 22 February 2012, para. 33.

80 Ministry of Justice. (2018) Op. cit.

81 Äripäev. (2019) Õiguskomisjon tahab välisinvesteeringute kaasamist lihtsustada. Äripäev, 9 September 2019. [online] Available from: https://www.aripaev.ee/uudised/2019/09/09/ oiguskomisjon-tahab-valisinvesteeringute-kaasamist-lihtsustada?fbclid=IwAR1XjLS2xr96vX KvdP6B-IF7hl1e11atM9zVxHmGR52GhBHWf4uMYj4xjTw [Accessed 20 September 2019]

82 Ibid.

83 Ibid, pp. 13-14. 
contract (in the UK and Denmark). ${ }^{84}$ Of the compared jurisdictions Germany was the only one that had the obligatory notarial authentication requirement for obligation-constituting contracts and real right contracts, while the Netherlands and Luxembourg had the same requirement only for real right contracts. The working group is not suggesting to entirely abolish the obligatory form requirement, but does propose a more flexible solution. The obligation constituting transaction could be form-neutral while the prescribed form for real right contract should either be notarial certification $^{85}$ or the electronic form ${ }^{86}$ instead of notarial authentication.

This idea of the working group should, however, be viewed together with a more stringent solution suggested for the shareholder ledgers. The idea of easing the form requirement for share transactions is linked to the suggestion of replacing the format-neutral shareholder ledger system with a notaries' monopoly to administer shareholder ledgers. ${ }^{87}$ The reasoning is understandable - reliability of the shareholder ledger entries. In summary, the idea of the working group is either to replace both of the current shareholder ledger administration alternatives - the CSD and management board - or merely to replace the latter with a notary-administered ledger solution.

In this context the legislature should also consider innovative technology solution (e.g. DLT) based ledger operators as possible gatekeepers in addition to notaries and CSDs. The legislature could introduce standards the ledger administrators would have to meet in order to maintain the ledger. This means the legislature does not have to necessarily introduce DLT-specific amendments like Delaware or France did, but instead should assess how to secure competition of ledger administrators for the benefit of the market and how to support innovation of the ledger maintenance practise without compromising on values and needed functions.

84 Ibid, p. 485.

85 According to Section 80(2) of GPCCA - the notarial certification means that the transaction documents shall be prepared in writing and the signature of the person entering into the transaction shall be certified by a notary (identification function).

86 Electronic form under Estonian law means the transaction is digitally signed and parties are identified under the electronic ID linked to the certificate of the digital signature (identification function).

${ }^{87}$ Ministry of Justice (2018) Op. cit., p. 119. Similar systems exist in Austria and Switzerland. 


\subsection{CONCLUSION}

As a summary of this theoretical application of the DLT-based ledger to the concerns identified above, it is noteworthy to state that assuming the DLT-based ledger application used would not lose its core characteristics the entries in the ledger would be instantaneous, verified and immutable transactions which would ensure the reliability of the ledger data. There would be no need to duplicate the ledger data into CR, yet, it would be possible to continue it for the sake of one source for all shareholder data. There would be no need for the notaries to ask for previous transaction documents or distrust the chain of control as due to linked timestamping and cryptography employed in the technology, the application would ensure transparency and immutability. The DLT-based ledger operator could also fulfil identification obligations under 5th AML Directive as virtual currency exchange service providers do.

Generally speaking DLT's attractiveness lies in that (i) it allows for operating a transparent public ledger, (ii) the ledger is accessible globally and easily, (iii) the ledger is resistant to tampering and employs a consensus mechanism, (iv) the protocol underlying the ledger is also tamper-proof as everyone can constantly verify it, and (v) the transactions amending the status of the ledger are verified by nodes. A DLT-based shareholder ledger can either be using the infrastructure of permissioned or permissionless network. The application layer can be built on the core protocol of the network using its infrastructure, yet, its own private rules of accessibility. The network could include - on the basis of the Delaware example - CR (or any other state authority) as one of the nodes verifying the transactions.

\section{TECHNOLOGY-NEUTRALITY IN LEDGER MAINTENANCE RULES}

After a brief introduction of the technology-neutrality principle, the regulation portrayed in section 3 is analysed on the basis of the said principle in order to address the research question of the article.

\subsection{TECHNOLOGY-NEUTRALITY PRINCIPLE}

The technology-neutrality principle is a classical non-discrimination principle, which initially required offline and online world to be treated 
equally. ${ }^{88}$ The principle was adopted more widely in the nineties with the advent of the Internet. In legal acts the principle is included in Article 20 of the Charter for Fundamental Rights, defined in Recital 18 and Article 8 of the Framework Directive ${ }^{89}$ (stating that regulation should neither impose nor discriminate in favour of the use of a particular type of technology) and supported by Recital 51 of NIS Directive ${ }^{90}$, which forbids to require certain product

"to be designed, developed or manufactured in a particular manner".

The assessment model to check the compliance of regulation with the principle of technology-neutrality can be separated into the following components:

1. Functional equivalence - the legislature should not discriminate between different technology (e.g. offline and online modes) in case these technologies have the same or similar functions;

2. Effects equivalence - regulation must have in majority an equivalent effect across different technologies even if it requires to have technology-specific legislation in place.

The aim of the principle is also to future-proof regulation - so that regulation does not hinder or create obstacles to innovation, but also would not need constant amendment. ${ }^{91}$

Technology-neutrality includes also media-neutrality, which means that the rules per different media or format should have a similar effect on the media used for a similar function or aim.

88 Reed, C. (2007) Taking Sides on Technology Neutrality. SCRIPTed 263 4(3) September 2007, pp. 263-284. [online] Available from: http://heinonline.org/HOL/P?h=hein.journals/scripted $4 \& \mathrm{i}=281$ [Accessed 01 June 2019].

89 Directive 2002/21/EC of the European Parliament and of the Council of 7 March 2002 on a common regulatory framework for electronic communications networks and services (Framework Directive). Official Journal of the European Union, L 108, 24. 4. 2002, pp. 33-50.

90 Directive (EU) 2016/1148 of the European Parliament and of the Council of 6 July 2016 concerning measures for a high common level of security of network and information systems across the Union (NIS Directive). Official Journal of the European Union, L 194, 19. 7. 2016, pp. 1-30.

91 Koops, B.-J. (2006) Should ICT Regulation be Technology-Neutral? In: Bert-Jaap Koops et al. Starting Points for ICT Regulation. Deconstructing Prevalent Policy One-Liners. IT \& Law Series. 9, pp. 77-108, The Hague: T.M.C. Asser Press 2006, p. 100. 


\subsection{IS THE CURRENT REGULATION TECHNOLOGY-NEUTRAL?}

\subsubsection{TECHNICAL REQUIREMENTS FOR THE LEDGERS}

Although majority of ledgers are maintained by management boards, these ledgers are not trusted by third parties. Ledgers administered by management boards are decentralised ledgers, maintained by individual companies themselves in any form they see fit. The CSD and the CR are centrally administered ledgers with the registrar under the supervision of an authority and regarded as public databases.

The regulation on the management board-administered ledger is technology-neutral as the CC does not prescribe that it must be in any particular media or form and therefore, it can be in any media or form or using any technology applications chosen by the management board. Consequently, any technology - DLT or other - can be used to administer the ledger as the regulation does not prefer a technology over another. The regulation has a similar effect on any technology and treats equally technology that functions similarly. Such approach makes the regulation actually technology-independent as it does not consider technology at all and even presumes the non-existence of technology being primarily focused on the subject who maintains and not the mechanism how it is maintained.

The ledger maintained by the CSD has technical standards applicable to it, requirements stemming from the law and public procurement terms. For the purposes of this article it is clear that any technological application the CSD wishes to use that is based on DLT needs to be separately assessed based on the applicable requirements. Due to the low usage of the CSD alternative in Estonia, it is not within the scope of this article to assess whether these requirements applicable to CSD are technology-neutral.

\subsubsection{SHARE TRANSFER REGULATION}

The differences of share transfer formalities on the basis of shareholder ledger maintenance begs the question: Why is there different treatment of shares and shareholders depending on the administrators they use? This question is based on the logic that CSD-registered share transfer transactions are form-neutral, while non-CSD transactions are not. In case of CSD-registered shares the transfer transaction form does not secure the fulfilment of any consulting or warning function. Also the evidentiary function is fulfilled only to a limited extent. Consequently, shareholders receive different protection by the regulation as it depends on the choice 
of administrator of the legal entity's shareholder ledger. It can be concluded that the form requirement differences are discriminatory towards non-CSD-registered shares and it is fair to conclude that the legislature simply does not consider consultation and warning function a necessary aspect of share transfer transactions for all shareholders across the board but requires these to be fulfilled only in case of non-CSD-registered share transfer transactions.

The irony in all this is that shareholder data ends up in the CSD on the basis of an application of the management board - the same management board who according to notary's practise cannot be trusted to submit correct data about shareholders and shares. Therefore, the claim that the CSD ledger data is in any way more trustworthy than management board ledger data is incorrectly based on the assumption that the data is somehow checked by the CSD when the management board registers the shares at the CSD. In truth, the shareholder data is not checked against any reliable source in any way by the CSD when the registration application is submitted by the management board. The mere fact that the shares are registered at the CSD does not make the data submitted there more reliable. However, any transactions executed that follow from the moment of registration are verified and parties of the transaction identified by the account operators.

It is fair to conclude that the differences of the share transfer requirements are administrator-specific and technology-independent, meaning that the rules do not care about how but rather about who. This means there exists a prejudice against ledgers maintained by management board irrelevant of the functions the ledger enables. On the one hand, the CSD ledger solution is carefully vetted by the state as part of a public procurement tender process for ledger maintenance, but on the other hand, the solutions used by the management boards for the same aim are not differentiated at all.

This is where the technology-independence actually works against the management boards as they should also be able to vet the solution they use for ledger maintenance. In short, this means that in case management boards would maintain shareholder ledgers using a technology that could at least fulfil identification function and up to a level evidentiary function similar to CSD - the share transfer transaction requirements applicable should be differentiated so that there would be effects equivalence among 
the alternative share ledger maintenance models (CSD and management board).

The effect of the existing regulation is discriminatory towards any technological solution used by the management board for ledger maintenance that enables the same functions as the CSD as such solution would not enjoy the same benefits of ease of liquidity as the CSD solution (form-neutral share transactions).

On the basis of principle of technology-neutrality the regulation should have the same or similar effect if there is functional equivalence of technology used. The fair application of this principle would demand the regulator to allow the management board to vet the solution used by it in order to establish whether its functionalities would make it possible for it to forgo the obligatory share transfer form of notarial authentication.

\subsubsection{ARE THE REFORM IDEAS TECHNOLOGY-NEUTRAL?}

The working group addressing the codification challenge has suggested that the shareholder ledger should be maintained solely by notaries. However, they would not operate as a separate ledger, but instead the notaries would be the gatekeepers of ledger data entered into the CR. Ledger data would be accessible through CR (through entries by notaries) or quite possibly also by CSD as the voluntary alternative, which would be also duplicated in the CR.

The suggested solution would centralise the administration of all shareholder ledger data into the hands of human intermediaries (i.e. notaries) and would, therefore, have a monopolising effect. In that case no technology use, however rich in functions, would be sufficient for ledger maintenance. Any such amendment of company law would have a negative effect on technology-neutrality and the use of any new technology, incl. DLT, for shareholder ledger administration as it would not allow any decentralized ledgers or gatekeepers at all.

A technology-neutral solution would be to enlist the functionalities the ledger needs to enable, the data categories it needs to collect and enable or even require these ledgers to send (or allow aggregation) of the ledger data into CR irrelevant of who is maintaining it (company itself or outsourcing the service). This would allow the management boards (by using market-developed and -led solutions), the CSDs (national or cross-border service providers) and notaries (hopefully not only 
Estonian) to function as gatekeepers of trustworthy, reliable and constituent shareholder ledger data that could be all aggregated into the CR in order to ease the consumption of the shareholder data by using one comprehensive data source.

This solution does not necessarily require that the solution used by management boards needs to be DLT-based, but it can be. It also does not mean the CR needs to duplicate the ledger data, but if the concern is the loss of unity of data as it is scattered around multiple sources, then this concern can be also addressed. All in all it means the regulator should think of ways to implement minimum technical standards set out in technology-neutral guidelines rather than centralizing the privilege to operate as an administrator with measures that support technology-independency and in effect do not grant technology a fair chance to prove that it is ready to replace some functions of humans (in this case notaries) without jeopardizing any of the functions the regulator wished to enable.

\section{CONCLUSIONS}

The article examined whether one could make use of new technological solutions, such as DLT, for administering a shareholder ledger of an OÜ in Estonia by applying technology-neutrality principle on the current regulation. Regarding the question of whether the use of DLT is allowed in ledger administration, the answer is at least partly affirmative. The legal rules in force regarding ledger administration by management boards are technology-neutral and do not give preference to or discriminate against any technology or medium.

The current technical requirements for ledger maintenance by management board are very light, yet the share transfer requirements are very strict. Even if the management board would voluntarily meet higher technical standards in ledger maintenance, this would not ease the strict share transfer form requirements. This means that the law does not recognize any technological solution the management board may use as fulfilling similar functions met by the technical solution used by CSD. The management board administered ledger is suffering a substantial disadvantage in comparison to CSD ledger due to share transfer form requirements (notarial authentication rule) and without any change in regulation a DLT-based ledger would suffer the same disadvantage. The codification working group suggestions aggravate the situation even 
further as accepting these would mean there is no decentralized ledger alternative anymore.

The effect of the current regulation is that there can be no alternative to CSD that could enjoy the ease of transfer and liquidity similar or even more advanced than CSD enjoys. All alternatives to CSD would have the same hindrances and obstacles to liquidity as the ledgers maintained by management boards under current regulation. The core separation between CSD and all alternatives is that CSD is a centralized ledger and management boards maintain decentralized ledgers. In order to comply with the technology-neutrality principle, the legal rules should be unified and made non-discriminatory from the point of view of decentralised and centralized ledger systems plus irrespective of the administrator of these systems. Such a change would allow the use of DLT for ledger maintenance purposes enjoying both access to and liquidity of the DLT-based networks and assets listed there enjoy. Consequently, amendments in regulation are needed to ensure technology-neutrality by implementing technical standardisation requirements and whichever ledger solution meets these can enjoy the same share transfer form freedom as CSD-registered shares. Alternative solution would be to introduce DLT-specific amendments to give DLT-based ledger maintenance applications that meet certain technical standards (similar to Delaware, US example) equal status with CSD-ledgers (as granted by the French DLT Order). Yet, it is not necessary to construct DLT-specific legislation as in the State of Delaware and France as also a more general approach could be introduced with either market-led or state-instituted technology-neutral standards or guidelines for all gatekeepers of shareholder ledgers.

The law should grant share transfer form freedom to any technological or human solution that through testing or validation process proves it fulfils the same functions as required for CSD share transfers. This could of course also mean that IT baseline security system requirements could be applied to these technological solutions, but these requirements should apply in a technology-neutral way.

In responding to the research questions the author also recognises that the pace of technological innovation is accelerating immensely. The way legislature has coped with technological innovation thus far has been through introducing technology-neutral regulation that would not create hindrances or obstacles to new technologies or their use cases. However, 
the pace of innovation makes it difficult for any legislature to cope with technology-neutrality principle as any change of technological innovation could challenge the neutrality of the regulation all over again. This is because technology-neutrality sometimes requires the introduction of amendments to ex ante laws in order not to exclude innovative business models or technology uses the same treatment as granted to as existing technology. Exactly this aspect of the principle of technology-neutrality is ever more difficult to address due to a "pacing problem" which means that

"technological innovation is increasingly outpacing the ability of laws and regulations to keep up". ${ }^{92}$

The pacing problem is further intensified by the "knowledge problem", which in the 21st century is no longer linked to insufficiency of information, but rather to overflow of information and the difficult task of understanding what information about technology is relevant for the legislature understand in order to create technology-neutral regulation.

The Estonian company law revision working group did not examine DLT as part of their analysis, which indicates the existence of a "pacing problem". Although any new technology could be a solution to the concerns of the current ledger administration system, the legislature and the working group procured with the codification task was not yet ready to assess the nascent technology's possible effects on the current practice. This means it is up to legal scholars to identify the problems the current regulation has in the context of technology-neutrality and suggest solutions in order to allow also new technology- DLT or any other - to be used in administrating shareholder ledgers in a meaningful way.

\section{LIST OF REFERENCES}

[1] Alekand A. Osaühingu osanikeregistri pidamine, Juridica I 2015. [online] Available from: https://www.juridica.ee/article_full.php?uri=2015_1_osa_hingu_osanikeregistri_ pidamine\&pdf=1 [Accessed 04 January 2019].

\footnotetext{
92 Thierer, A. (2018) The Pacing Problem, the Collingridge Dilemma \& Technological Determinism. [blog entry] The Technology Liberation Front blog (16 August 2018). Available from: https://techliberation.com/2018/08/16/the-pacing-problem-the-collingridge-dilemmatechnological-determinism/ [Accessed 27 January 2019].

$93 \quad$ Ibid, p. 37.
} 
[2] Allison, I. Smart securities issuer Symbiont fires shots in the private blockchain arms race. International Business Times, 28 September 2015. Available from: https://www.ib times.co.uk/smart-securities-issuer-symbiont-fires-shots-private-blockchain-arms-race1521449 [Accessed 08 May 2018].

[3] Case no 3-2-1-133-11 (2011), Estonian Supreme Court (Civil Chamber), 14 December 2011.

[4] Case no 3-2-1-141-14 (2015), Estonian Supreme Court (Civil Chamber), 28 January 2015.

[5] Case no 3-2-1-163-11 (2012), Estonian Supreme Court (Civil Chamber), 22 February 2012.

[6] Case no 3-4-1-3-12 (2012), Estonian Supreme Court (Constitutional Review Chamber), 6 July 2012.

[7] Chamber of Notaries. (2018) Notarite Koja arvamus ühinguõiguse revisjoni muudatusettepanekute kohta (Opinion to the analysis-concept paper of company law revision working group), 17th December 2018. [online] Available from: https://www.just.ee/sites/ www.just.ee/files/notarite_koja_arvamus_18.12.2018.pdf [Accessed 12 January 2019].

[8] Clifford Chance (2017). France pioneers blockchain legal framework for unlisted Securities, Briefing Note. [online] Available from: https://www.cliffordchance.com/ content/dam/cliffordchance/PDFDocuments/Client\%20Briefing\%20-\%20France $\% 20-\% 20$ Blockchain\%20for\%20unlisted\%20securities\%20180750-4-2....pdf [Accessed 08 May 2018].

[9] Collingridge, D. (1981) The Social Control of Technology. Open University Press.

[10] Commercial Code (Äriseadustik) 1995. Estonia: Riigi Teataja (State Gazette). RT I 1995, 26, 355, in Estonian. English translation available from: https://www.riigiteataja.ee/en/eli/507 012019006/consolide [Accessed 09 February 2019].

[11] ConsenSys. (2018) Wyoming Passes 5 Pro-Blockchain Laws, Points the Way in Digital Asset Regulation (15 March 2018). Available from: https://media.consensys.net/wyoming -passes-5-pro-blockchain-laws-points-the-way-in-digital-asset-regulation-6fae9e07d129 [Accessed 27 January 2019].

[12] Cuccuru, P. (2017) Beyond bitcoin: An early overview on smart contracts. International Journal of Law and Information Technology, 25 (3). [online] Available from: https:/doi.org/ 10.1093/ijlit/eax003 [Accessed 30 May 2018].

[13] De Filippi, P., Wright A. (2018) Blockchain and the Law: The rule of code. Harvard University Press.

[14] Decree of the Minister of Justice no 60. (2012) Statute of the registry department of the court (Kohtu registriosakonna kodukord), 19 December 2012, RT I, 28. 12. 2012, 10.

[15] Delaware State Senate 149th General Assembly Senate Bill No. 69. An act to amend title 8 of the Delaware Code Relating To The General Corporation Law. [online] Available 
from: https://legis.delaware.gov/json/BillDetail/GenerateHtmlDocument?legislationId=25 730\&legislationTypeId=1\&docTypeId=2\&legislationName=SB69 [Accessed 07 May 2018].

[16] Directive 2002/21/EC of the European Parliament and of the Council of 7 March 2002 on a common regulatory framework for electronic communications networks and services (Framework Directive). Official Journal of the European Union, L 108, 24. 4. 2002.

[17] Directive 2009/101/EC of the European Parliament and of the Council of 16 September 2009 on coordination of safeguards which, for the protection of the interests of members and third parties, are required by Member States of companies within the meaning of the second paragraph of Article 48 of the Treaty, with a view to making such safeguards equivalent (Text with EEA relevance). OJ L 258, 1. 10. 2009.

[18] Directive (EU) 2016/1148 of the European Parliament and of the Council of 6 July 2016 concerning measures for a high common level of security of network and information systems across the Union (NIS Directive). Official Journal of the European Union, L 194, 19. 7. 2016.

[19] Directive (EU) 2017/1132 of the European Parliament and of the Council of 14 June 2017 relating to certain aspects of company law (Text with EEA relevance). OJ L 169, 30. 6. 2017.

[20] Estonian Central Register of Securities Act (Eesti väärtpaberite keskregistri seadus) 2001. Estonia: Riigi Teataja (State Gazette). RT 2000, 57, 373, in Estonian. English translation available from: https://www.riigiteataja.ee/en/eli/ee/519112013006/consolide [Accessed 09 February 2019].

[21] European Commission (2019). Communication from the Commission to the European Parliament, the Council, the European Central Bank, the European Economic and Social Committee and the Committee of the Regions FinTech Action plan: For a more competitive and innovative European financial sector. Brussels, 8. 3. 2018 COM(2018) 109 final (9 January 2019). Available from: https://eur-lex.europa.eu/resource.html?uri=cellar: 6793c578-22e6-11e8-ac73-01aa75ed71a1.0001.02/DOC_1\&format=PDF

[Accessed 23 January 2019].

[22] Explanatory memorandum (744 SE) to the Act amending Commercial Code, Non-Profit Associations Act, Foundations Act and acts related to the above Äriseadustiku, mittetulundusühingute seaduse, sihtasutuste seaduse ning nendega seotud seaduste muutmise seaduse eelnõu 744 SE seletuskiri, 15 December 1997. Available from: https://www.riigi kogu.ee/tegevus/eelnoud/eelnou/cf759bd3-97aa-310b-bb84-4bc734d83249/\%C3\%84 riseadustiku, \%20mittetulundus\%C3\%BChingute\%20seaduse, $\% 20$ sihtasutuste $\% 20$ 
seaduse $\% 20$ ning $\% 20$ nendega $\% 20$ seotud $\% 20$ seaduste $\% 20$ muutmise $\% 20$ seadus [Accessed 07 January 2019].

[23] Family Law Act (Perekonnaseadus). 2009 Estonia: Riigi Teataja (State Gazette) RT I 2009, 60, 395, in Estonian. English translation available from: https://www.riigiteataja.ee/en/eli/ 507022018005/consolide [Accessed 09 February 2019].

[24] General Part of the Civil Code Act (Tsiviilseadustiku üldosa seadus) 2002. Estonia: Riigi Teataja (State Gazette), RT 2002, 35, 216, in Estonian. English translation available from: https://www.riigiteataja.ee/en/eli/502012019003/consolide [Accessed 09 February 2019].

[25] Guardtime (2019). [online] Available from: https://guardtime.com/technology [Accessed 14 January 2019].

[26] Koops, B.-J. (2006) Should ICT Regulation be Technology-Neutral? In Bert-Jaap Koops et al. Starting Points for ICT Regulation. Deconstructing Prevalent Policy One-Liners. IT \& Law Series, 9. The Hague: T.M.C. Asser Press, 2006.

[27] Korjus, K. (2017) Welcome to the blockchain nation. [blog entry] Medium Blog (7 July 2017). Available from: https://medium.com/e-residency-blog/welcome-to-the-blockchain-nation -5d9b46c06fd4 [Accessed 20 January 2019].

[28] Kõve V. (2013) Kas kinnistusraamatu ja teiste kohtulike registrite korraldus vajab reformi? Juridica VII 2013. Available from: https://www.juridica.ee/article_full.php?uri= 2013_7_kas_kinnistusraamatu_ja_teiste_kohtulike_registrite_korraldus_vajab_reformi_\& pdf $=1$ [Accessed 01 January 2018].

[29] Law of Obligations Act (Võlaõigusseadus) 2001. Estonia: Riigi Teataja (State Gazette) RT I 2001, 81, 487, in Estonian. English translation available from: https://www.riigiteataja.ee/ en/eli/508082018001/consolide [Accessed 09 February 2019].

[30] Law of Property Act (Asjaõigusseadus) 1993. Estonia: Riigi Teataja (State Gazette) RT I 1993, 39, 590, in Estonian. English translation available from: https://www.riigiteataja.ee/ en/eli/502012019009/consolide [Accessed 09 February 2019].

[31] Long, C. (2018) Blockchain crosses the Delaware. [blog entry] Mediamarkets blog, 31 July 2018. Available from: https://www.marketsmedia.com/blockchain-crosses-delaware/ [Accessed 07 May 2018].

[32] Lucking, D. (2017) Delaware Passes Law Permitting Companies to Use Blockchain Technology to Issue and Track Shares. Allen \& Overy publications, 26 September 2017. [online] Available from: http://www.allenovery.com/publications/en-gb/Pages/Delaware-PassesLaw-Permitting-Companies-to-Use-Blockchain-Technology-to-Issue-and-Track-Shares.aspx [Accessed 05 May 2019]. 
[33] McCorry, P., Hicks, A., and Meikeljohn, S. (2018) Smart contracts for bribing miners. Conference Proceedings The 5th Workshop on Bitcoin and Blockchain Research, 2nd March 2018. Available from: https:/fc18.ifca.ai/bitcoin/schedule.html [Accessed 03 May 2018].

[34] Ministry of Justice. The Draft Core Assignment of the Codification of Company Law (Ühinguõiguse kodifitseerimise lähteülesande projekt), 2014. Available from: https://www.just. ee/sites/www.just.ee/files/uhinguoiguse_kodifitseerimise_lahteulesande_projekt_0.pdf [Accessed 12 January 2019]

[35] Ministry of Justice. (2018) Revision of Company Law, Analysis-Concept Paper (Ühinguõiguse revisjon Analüüs-konseptsioon), 15 September 2018. [online] Available from: https://www.just.ee/sites/www.just.ee/files/uhinguoiguse_revisjoni_analuuskontseptsioon.pdf [Accessed 12 January 2019].

[36] Nakamoto, S. (2008) Bitcoin: Peer-to-peer Electronic Cash System. [online] Available from: https://bitcoin.org/bitcoin.pdf [Accessed 12 April 2018].

[37] Nicholson, G. (2019) Wyoming Proposes Bill for Issuance of Tokenised Certificates with Stocks. TokenMarket (17 January 2019). Available from: https://tokenmarket.net/news/ regulation/wyoming-proposes-bill-issuance-tokenised-certificates-stocks/ [Accessed 23 January 2019].

[38] O'Toole, M. J., Reilly, M. K. (2017) The First Block in the Chain: Proposed Amendments to the DGCL Pave the Way for Distributed Ledgers and Beyond. Harvard Law School Forum on Corporate Governance and Financial Regulation, 16 March 2017. Available from: https://corpgov.law.harvard.edu/2017/03/16/the-first-block-in-the-chain-proposedamendments-to-the-dgcl-pave-the-way-for-distributed-ledgers-and-beyond/\#3 [Accessed 30 April 2017].

[39] Polner, G. et al. (2017) Delaware Approves Use of Blockchain in New DGCL Amendments. Gibson Dunn Securities Regulation and Corporate Governance Monitor. 31 July 2017. [online] Available from: http://securitiesregulationmonitor.com/Lists/Posts/Post .aspx?ID=299 [Accessed 07 May 2018].

[40] Proposal HB0185 Corporate stock-certificate tokens. [online] Available from: https://www.wyoleg.gov/Legislation/2019/HB0185 [Accessed 23 January 2019].

[41] Public Information Act (Avaliku teabe seadus) 2001. Estonia: Riigi Teataja (State Gazette). RT I 2000, 92, 597, in Estonian.

[42] Reed, C. (2007) Taking Sides on Technology Neutrality. SCRIPTed 2634 (3), September. [online] Available from: http://heinonline.org/HOL/P?h=hein.journals/scripted4\&i=281 [Accessed 11 April 2018]. 
[43] Regulation (EU) No 909/2014 of the European Parliament and of the Council of 23 July 2014 on improving securities settlement in the European Union and on central securities depositories and amending Directives 98/26/EC and 2014/65/EU and Regulation (EU) No 236/2012 Text with EEA relevance. OJ L 257, 28. 8. 2014 (CSDR).

[44] Report to the President of the Republic relating to Ordinance No. 2017-1674 of 8 December 2017 on the use of a shared electronic registration device for the representation and transmission of financial securities, Rapport au Président de la République relatif à l'ordonnance $n^{\circ}$ 2017-1674 du 8 décembre 2017 relative à l'utilisation d'un dispositif d'enregistrement électronique partagé pour la représentation et la transmission de titres financiers. Published in JORF $\mathrm{n}^{\circ} 0287$ du 9 décembre 2017 texte $\mathrm{n}^{\circ} 23$. [online] Available from: https://www.legifrance.gouv.fr/eli/rapport/2017/12/9/ECOT1729053P/jo/ texte [Accessed 01 May 2018].

[45] Saare K. et al, Ühinguõigus I, Juura, 2015.

[46] Securities Register Maintenance Act (Väärtpaberite registri pidamise seadus) 2017. Estonia: Riigi Teataja (State Gazette). RT I, 26. 06. 2017, 1, in Estonian. English translation available from: https://www.riigiteataja.ee/en/eli/511012018001/consolide

[Accessed 10 February 2019].

[47] Sein, K. Tehingu vorminõuded ja nende järgimata jätmise tagajärjed, Juridica VII/2010.

[48] Shaan, R. The Difference Between Blockchains \& Distributed Ledger Technology. [blog entry] Medium Blog Towards Data Science. Available from: https://towardsdatascience.com/the -difference-between-blockchains-distributed-ledger-technology-42715a0fa92 [Accessed 01 May 2018].

[49] Song, W. (2018) Bullish on blockchain: examining Delaware's approach to distributed ledger technology in corporate governance law and beyond. Harvard Law Review. Available from: http://www.hblr.org/2018/01/bullish-on-blockchain-examiningdelawares-approach-to-distributed-ledger-technology-in-corporate-governance-law-andbeyond/ [Accessed 07 May 2018].

[50] State Information System Website. [online] Available from: https://www.ria.ee/en/cybersecurity/it-baseline-security-system-iske.html [Accessed 02 June 2019].

[51] Stromberg G. T. et al. (2018) Are Headwinds Hampering Delaware's Blockchain Initiative? Law 360, 23 March 2018. Available from: https://jenner.com/system/assets/ publications/17844/original/stromberg\%20Law360\%20March\%2023\%202018.pdf?1521837 416 [Accessed 14 January 2019]. 
[52] Thierer, A. (2018) The Pacing Problem, the Collingridge Dilemma \& Technological Determinism. [blog entry] The Technology Liberation Front blog (16 August 2018). Available from: https://techliberation.com/2018/08/16/the-pacing-problem-thecollingridge-dilemma-technological-determinism/ [Accessed 27 January 2019].

[53] Veerpalu, A. (2018) Decentralised Technology and Technology Neutrality in Legal Rules: An Analysis of De Voogd and Hedqvist. Baltic Journal of Law E Politics, 11 (2). [online] doi: https://doi.org/10.2478/bjlp-2018-0011

[54] Wikipedia. (2018) Corda. [online] Available from: https://en.wikipedia.org/wiki/R3 (company)\#Corda [Accessed 14 January 2018].

[55] Wikipedia. (2019) Ethereum. [online] Available from: https:/en.wikipedia.org/wiki/ Ethereum [Accessed 14 January 2019].

[56] Vocabulary of Computing (list terms, expressions and definitions adopted). Vocabulaire de l'informatique (liste de termes, expressions et définitions adoptés) published in JORF n0121 du 23 mai 2017 texte $n^{\circ} 20$. Available from: https://www.legifrance.gouv.fr/affichTexte. do?cidTexte=JORFTEXT000034795042\&categorieLien=id [Accessed 01 May 2018].

[57] Äripäev. (2019) Õiguskomisjon tahab välisinvesteeringute kaasamist lihtsustada. Äripäev, 9 September 2019 [online]. Available from: https://www.aripaev.ee/uudised/2019/09/09/ oiguskomisjon-tahab-valisinvesteeringute-kaasamist-lihtsustada?fbclid=IwAR1XjLS2xr9 6vXKvdP6B-IF7hl1e11atM9zVxHmGR52GhBHWf4uMYj4xjTw [Accessed 20 September 2019]. 